\title{
Jerry Brotton. This Orient Isle: Elizabethan England and the Islamic World. London: Allen Lane, 2016. Pp xv, 358.
}

\author{
RICHARD ALLEN CAVE
}

Royal Holloway, University Of London

This book is remarkable both for its timeliness and topicality (it offers a detailed history of the negotiations between Elizabeth I and her advisers with the complex political structures of the Islamic world in the Mediterranean and the Near East) and for the impressive range of its scholarship, which calls on a knowledge of Islamic philosophy, Elizabethan social, cultural and political history, the relations throughout the sixteenth century between England, Spain, France, the Netherlands, Portugal, Russia, the Papacy, and Venice, the histories of Morocco, the Ottoman Empire and Persia, Renaissance cartography, architecture, the iconography of late Tudor painting, and, crucially, the evolution of English drama and theatre, particularly in the years between 1576 and 1603, when by the author's computation Islamic themes, characters, and plots appeared in some sixty plays. The wide scope of the material is throughout disciplined by a meticulous sense of precise relevance and the careful relating of details to define patterns of significance within seemingly disparate fields. Brotton communicates with a wit and a refreshing clarity that make the volume a joy to read.

The first half of the monograph focuses on the twin themes of politics and trade, chiefly in the wake of Elizabeth's excommunication in 1570, which left England dangerously isolated in Europe, when tentative approaches were made to various Muslim leaders with a view to forming alliances against Spain. But alliances are costly and two-way trade negotiations became the means to support the political initiatives: the whole intricate endeavour, as Brotton tartly puts it, was motivated less by 'natural amity and tolerance' than 'expediency and realpolitik' (9). Trading was often a cover to keep Elizabeth and Walsingham's more serious intentions hidden from their enemies and from critics at home; yet these were significantly the years that saw the establishing of the Muscovy Company (pursued strategically to gain passage through Ivan the Terrible's kingdom to routes leading to Persia and the Sophy), the Barbary Company, the Turkey Company and the Venice Company (the latter two eventually being merged to form the Levant Company). England sought to improve and maintain its security and the evidence of success in that venture was the extent to which strange but desirable commodities flooded English markets, including spices, fruit and nuts; damask, velvets and other furnishing and dressing fabrics; silk and, in time, the means 
to manufacture it at home; carpets and hangings; sugars and either saltpetre for gunpowder or the ingredients to make it. Brotton's approach encourages us to look again at familiar portraits of the period and note (what we might casually overlook) the material goods with which sitters chose to adorn or surround themselves, all indicative of the degree to which Islamic artefacts infiltrated wealthier homes and institutions. In return English merchants more prosaically exported woollen cloth, chiefly kersey, and scrap metal for the making of guns. Both initiatives (diplomatic and commercial) were frequently affected adversely by regime changes within the courts to which the English sedulously made overtures, inevitably centring on conflicts between Sunni and Shi'a factions within realms. English tenacity won out, even when on occasion the spanner in the works was of English origin, such as the international mayhem created by the opportunistic braggart, Sir Anthony Sherley, who for his own gain tried to play off the various nations, European and Muslim, who were seeking to control the Mediterranean, while officially both representing Elizabeth and heading an embassy from the Sophy of Persia to various Christian heads of state. All these overtures by Walsingham or Leicester's agents were justified from a theological and philosophical perspective on the ingenious grounds that Islam, like Protestantism, eschewed the worshipping of idols and icons and the focus of faith was also a holy book. The most productive of the initiatives (and arguably the most sustained) was with al-Mansur of Morocco, whose forces joined with the English in the attack on Cadiz (1596). He planned a united Moroccan-English force to attack the Spanish in their American colonies and, to further this ambition, sent an ambassador, Muhammad al-Annuri, to Whitehall in 1600, where he attended the AccessionDay Tilt, exchanged gifts and talked with the queen, and roused considerable suspicion amongst Londoners with his largely black entourage. Al-Annuri was a Morisco by birth, a paler-skinned Moor (his anonymous but magnificently realized portrait now graces the collections of the University of Birmingham); he left London a matter of weeks before Shakespeare began writing Othello.

The volume somewhat cycles back on itself in the second half when the focus turns more precisely to the cultural repercussions of the events. The author made a wise decision to structure the book in this way, since it allows a reader to get a grasp on the full history of the developments in Anglo-Muslim relations as outlined in the opening chapters, the better to appreciate the changing values, styles, and levels of insight that influenced the representation of Muslims on the Elizabethan stage. Brilliantly, Brotton engages with issues of reception, teaching us how to read anew with developed historical insight often familiar lines, situations, and characters by showing us the kinds of awareness and knowledge of the 
Muslim world available to original audiences, which must have influenced their appreciation of the plays in performance. How widely news of English trafficking in Muslim territories circulated and within what ranks is a vexed question. If the stage was the prime vehicle of transmission, then highly distorted versions of what was actually happening would have been current, but that misrepresentation may well have suited Walsingham's secretive ploys. What is clear is that Muslim narratives, however farfetched some of these were in the popular imagination, were a gift to dramatists eager to abandon the tight moral frameworks that had controlled dramaturgy till then, by allowing them to confront, explore and stage ambiguity. Brotton shows how Marlowe's characterizing of Tamburlaine creates unease in spectators by almost simultaneously exciting horror at his cruelty and excitement at the brilliance of his fiery and seductive rodomontade (160-6). Action is not suited to word in the two plays but often fiercely opposed to disturbing effect, which saves Marlowe's characterisation from being a stereotypical reduction of his hero to an objectified other, since a strong element of complicity is involved in the lure of Tamburlaine's dynamism (163). Brotton argues that a similar complexity of response that avoids stereotyping appears in Kyd's 'Soliman and Perseda' in the last act of The Spanish Tragedy and in the diverse range of Muslim characters in Peele's The Battle of Alcazar (166-8). Lesser dramatists (Dekker, Fulke Greville, Day, and Haughton) were in Brotton's analysis less scrupulous and significantly less successful, while Marlowe, ever experimental, pushed levels of audience unease to an alarming degree in The Jew of Malta by exploring a dramatic world where energy is not matched by poetic fervour, because Malta is a world without vision, where only commercial transactions obtain politically. There is no 'othering' in a play where Jew, Muslim, and Christian are equally offensive (178-81).

Brotton concludes by discussing how Shakespeare subtilized and problematized what he inherited from his predecessors. With the whole weight of the book behind him, he can demonstrate the complexities that underlie lines like Sir Toby describing Viola to the terrified Sir Andrew as 'fencer to the Sophy' (235-6); the First Witch in Macbeth referring to her victim's husband as 'to Aleppo gone, Master o' th' Tiger' (123); or Desdemona's mother's maid poignantly bearing the generic name 'Barbarie' (292-3). The wealth of reference implicit in these phrases would defy conventionally terse annotation. He compares Shakespeare's three portrayals of Moors (Aaron, the Prince of Morocco and Othello), distinguishing growing insight and engagement in the terms of their presentation, when the three roles are viewed in sequence chronologically. He interprets Aaron as embodying the failures of the 'civilised' world that is Rome, the dark indeterminacies which 
inhabit the gaps between Roman rhetoric and their callous practice (196). Persuasively, Brotton gives Morocco a more generous reading than is generally offered in productions, endowed with a dignity quite superior to hints of caricature (2024). But Othello undergoes the most searching analysis in terms of the conflicting impulses, pressures and expectations that define his increasingly wounded psyche, as he moves under Iago's agency from confidence in himself to an unsure player of roles, even staging himself as 'turbaned Turk' in his dying (281-97). In a context that has encompassed the tangled history of relations between Ottomans, Moors, and Jews, Brotton defends the 1623 Folio reading of the textual crux 'Iudean' as Othello prepares to commit suicide, as distinct from 'Indian', the more popular reading from the 1622 Quarto. He sees the crux as irresolvable, but argues the two readings strikingly capture 'Othello's overdetermined character, part Muslim, Christian, Jew and even pagan' (295): the ultimate tragedy of being 'other'. Othello never learns who fundamentally he is; Iago, the corrupt European, by colonizing his mind, has seen to that. 